\title{
Sælhundefangst med Rømø-skibe
}

Af Bert Kelm

Rømøs "guldalder«, 1700-tallet, var præget af hval- og sælfangsten, der bragte betydelig velstand til øen i denne periode. Hundredevis af søfolk fra Rømø sejlede til Grønland, både fra Hamborg, Amsterdam, Flensborg og andre steder, hvor skibe udrustedes til hval- og sælfangst. $P a ̊$ grund af deres dygtighed var de meget efterspurgte blandt redere, adskillige fik officersrang, og mange blev kommandører.

\section{Hvad der findes trykt}

Der er efterhånden megen litteratur om disse forhold; men det vides ikke med sikkerhed om Rømø deltog med dér hjemmehørende skibe. I Staatsbürgerliches Magazin fra 1834 berettes, at man »drev Grønlandsfart, til dels for egen regning og med egne skibe, som der i sin tid skal have været 16 af på øen «. ${ }^{1}$ Dette er næppe rigtigt. Ingen historisk kilde omtaler så stor en flåde, og til de større hvalfangstskibe fandtes der heller ingen havn til overvintring $i$ området. Men det er dog tænkeligt, at nogle kommandører havde anparter i de skibe, de sejlede med fra ovennævnte store havne.

Carl Pontoppidan skriver i Hval- og Robbefangsten i 1785, "Robbeeller Sælhundefangsten fra Dannemark er begyndt omtrent for 100 Aar siden, da nogle fra Eilandet Romøe i Riber Stift, i Samqvem med andre fra Helgeland, begyndte at fare paa Robbenslageriet under Jan Mayn med smaae skibe, deels eenmastede Galioter, deels Kreyerter, deels Hukkertbygninger, hvorfra og i mange Aar udgik aarlig 10 til 11 Skibe med stor Fordel paa denne Fangst «. ${ }^{2}$

Og »Paa Eilandet Romøe har og været et Tranbrænderie, der for faae Aar siden er nedlagt, da aarlig 3 á 4 Skibe gik derfra paa Robbefangst; Aarsagen er, muligt, at Havnen er bleven alt for flak $\aleph^{3} \mathrm{C}$. Norman holder sig til disse oplysninger i $1867,{ }^{4}$ og også nyere forfattere Wanda Oesau, ${ }^{5}$ Thade Petersen, ${ }^{6}$ H. E. Sørensen 7 og F. J. Falk ${ }^{8}$ nævner samme overleveringer, men sætter dog mere eller mindre spørgsmåltegn ved dem.

Hvordan kan man så finde ud af sandheden? 


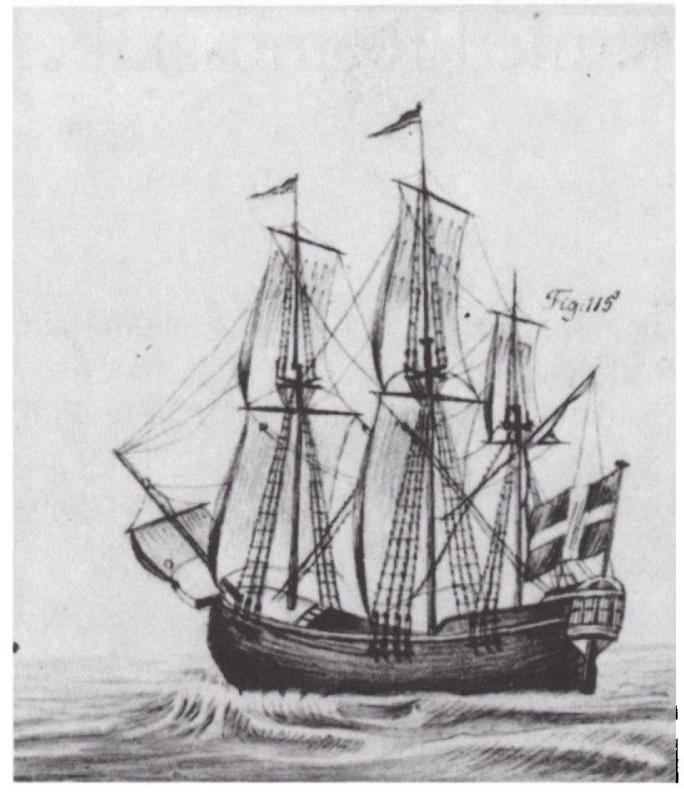

En kreyert. Efter G.A.Kofoeds soordbog ca. 1780. (Handels-og sefartsmuseet pd Kronborg)

\section{List toldregnskaberne som hovedkilde}

Der er bevaret nogle toldregnskaber fra List toldsted, der giver oplysninger om skibsfarten gennem Lister $\mathrm{Dyb}$, for enkelte år i perioden mellem 1731 og 1769 selve toldbøgerne, for perioden mellem 1680 og 1771 dertilhørende revisions-antegninger.9 Ganske vist må man være klar over, at regnskaberne ikke kan give et fuldstændigt billede af skibsfarten i området. Der fandtes f.eks. skibe hjemmehørende på Rømø eller List, der sejlede mellem store havne som Amsterdam, Hamborg, Newcastle og til Østersøen, uden at de nødvendigvis passerede Lister Dyb. Det samme gjaldt for skibsfarten fra Ribe. Således sejlede Lauritz Lauritzen af Rømø i 1767 med et skib på 25 læsters størrelse (ca. 50 tons) to gange turen fra Ribe til Riga hhv. Memel for Ribe-rådmanden Rahrs regning, uden at komme gennem Lister Dyb. ${ }^{10}$ Tolden klareredes vist nok i Ribe.

Nogle skibe må også have passeret toldstedet uden registrering. I hvert fald klager viceadmiral M. Poulsen fra Glückstadt den 13. juni 1695 over, at danske og svenske »Frantzfahrer« (deltagere i de dengang, p.g.a. krigsforholdene og sørøveri, i konvojer organiserede handelsskibes fart til Frankrig) sejler gennem Lister Dyb og losser i danske og 
fremmede smakker, der bringer varer videre til Hamborg og andre steder uden at betale told." Allerede den 6. juli 1695 blev der svaret fra København, at alle undtagen svenskerne skulle anholdes. I 1693 fandtes der i øvrigt en kreyert "Egernen«, 57 l. stor, af Emmerlev, blandt disse $"$ Frantzfahrer . $^{12}$

Trods disse usikkerheder giver toldregnskaberne et godt og pålideligt indtryk af forholdene omkring Lister Dyb. Men inden vi går nærmere ind på deres udbytte, skal vi se på en anden kilde, der sammen med regnskaberne giver gode oplysninger om situationen ved udgangen af 1600-tallet.

\section{En skibsliste fra 1677}

Der blev udarbejdet skibslister for søværnet med det formål at skaffe kendskab til mulighederne for troppetransport. ${ }^{13}$ En sådan liste er bl.a. udfærdiget af Hans Outzen i Brøns i december 1677:

"Forteignelse paa huis Schibe som ligger i Konsmarck Laa ved Römme under Haderslefhusis Rettighed.

Anders Præst i Jyffre en Smack, dregtig 9 Læster, kand indtage Øxsen 28 eller 30 . Gaar med sin Ladning dybt $4 \frac{1}{2}$ Foed.

Peder Smed i Bolilmarck, en Galliot, er ikke andet tjenlig, end at tage Korn eller Brændeved ind, er dregtig 12 Læster. Gaar med sin Ladning dybt 7 Foed.

Peder Michelsen en gammel Smack, aff 24 Aar gammel, er dregtig 6 Læster. Kand indtage Øxsen 22 eller 24. Gaar med sin Ladning dybt $4 \frac{1}{2}$ Foed.

Christen Bolsersen angaff $\frac{1}{4}$ Part at hafue $i$ en gammel Smack, med Bagge Baggesen i Ribe, som ligger i Riber Aae, dregtig 10 Læster. Kand indtage $\emptyset x$ xen 30 eller 32. Gaar med sin Ladning dybt 5 Foed.

Jesper Hansen i Konsmarck en Smack, dregtig 8 Læster. Kand indtage $\varnothing x \operatorname{sen} 44$. Gaar med sin Ladning dybt 6 Foed.« 


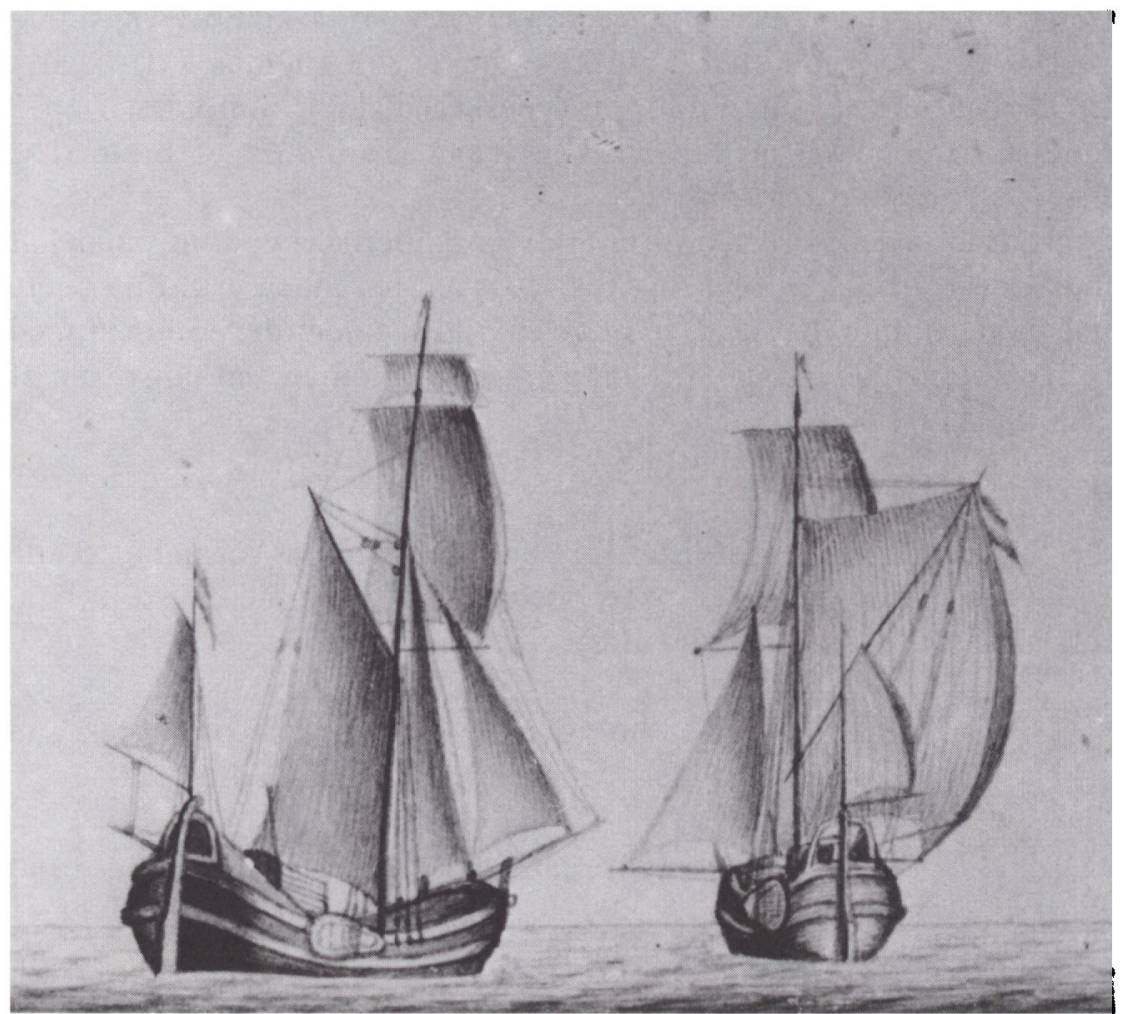

En smakke og en tjalk, tegnet af Brdr. Stibolt i 1760'erne. (Handels-og sofartsmuseet pd Kronborg)

Derefter følger 2 skibe med 8 hhv. 12 Læster af Hoyer, og listen fortsætter:

"Herforuden befindes 8 Smacker under Graff Schacks Rettighed, som ligger sønderst på Römmis Haffn, och ere paa 5 och 4 Læster, som sejler til Hamborg med Østerling, ochsaa med Korn til Oldenburg och paa Elven, dog di ikke hafer værit udi Østersøen.

Dette forschrefne er ... effter Schippernis deris egen Bekiendelse och angiffuen, dog tvifles ej, at jo it huert Schib eller 
Schmacke kand være noget større, och føre nogit mere end som af Schipperen angiffues.«

Hvad angår skibenes størrelse og antal på Sønderlandet, så findes der alene 8 smakker af 6 læsters og en af 4 læsters størrelse fra øens sydlige del $\mathrm{i}$ toldregnskabet $1682 / 83$. Derudover må der have været et større antal små både, der brugtes til østersfiskeri. Dette erhverv havde dengang stor betydning for Rømø. Østersbankerne mellem Rømø og fastlandet gjaldt ved århundredeskiftet $1600 / 1700$ som overfisket. I 1699 og 1704 nævnes der under to retssager på Ballum ting, der skulle klare forholdene, 15 hhv. 17 mænd fra Rømø, der havde særligt kendskab til østersfiskeri, efter egne udsagn i op til 40 år. ${ }^{14}$

Det er meget tvivlsomt, om et af skibene fra listen blev brugt til grønlandsfart. Et principielt egnet skib, Peder Smeds 12 læsters galiot, findes i mange år indtil 1690 som handelsskib, således f.eks. 1683 med trælast fra Norge, ${ }^{15}$ og 1686 med diverse slags gods 2 gange på ruten Bergen-Køge, efter at han havde bragt 34 tønder østers til København den 11. april. ${ }^{16} \mathrm{Han}$ var med danske tropper ved det store Englandstogt i oktober $1689,{ }^{17}$ og 1690 findes han i en omfattende skibsliste fra List toldsted, der i alt nævner 129 fartøjer, deraf 20 mindländische«. Resten er »udländische« og nogle »tractat priviligerede«, begge slags åbenbart hjemmehørende i hertugdømmerne. ${ }^{18}$ Peder Smeds galiot »Haabet er trods hjemsted på Nørland Rømø betegnet som »indländisch«. Listen anfører i øvrigt næsten kun smakker, åbne skuder og både. Der nævnes i alt 1 evert og 3 galioter.

Foruden alle disse skibe, mest smakker, der brugtes til varetransport i kystområdet og fra Norge, findes der ud over den før nævnte kreyert af Emmerlev ingen henvisninger til andre, større skibe, hverken i skibslister eller $i$ toldregnskabernes optegnelser for tiden fra 1680 og ind i 1700-tallet. Heller ikke varelister fra samme periode indeholder noget - bortset fra tran - der kunne være knyttet til sælfangst. ${ }^{19} \mathrm{Og}$ tranen, omkring 50 tønder årligt, synes at være blevet importeret udefra, som en toldsag fra 1682 viser. ${ }^{20}$

Der findes ligeledes ikke noget som helst om skibsfarten fra Helgoland $\mathrm{i}$ denne tid. Da Rømø havde tæt forbindelse med Helgoland $\mathrm{i}$ 1400- og 1500-tallet i den store sildefangstperiode, kan man ikke helt udelukke, at nogle mænd fra Rømø sammen med helgolændere tog på sælhundefangst i 1600-tallet fra Helgoland. Der findes hverken bevis for eller imod. 


\section{Tabel 1. Salfangstskibe $i$ List toldregnskab}

\section{Forkortelser:}

$\mathrm{t}$ - toldbog, a - antegnelser, $\mathrm{g}$ - galiot, $\mathrm{h}$ - hukkert

E - England, F - Frankrig, H - Holland, N - Norge, S - Sverige (Gotland)

\begin{tabular}{|c|c|c|c|c|c|c|c|c|c|c|c|}
\hline \multirow[b]{2}{*}{$\begin{array}{l}\text { Ár og } \\
\text { kilde }\end{array}$} & \multirow[b]{2}{*}{ Kommandørens navn } & \multirow{2}{*}{$\begin{array}{l}\text { Skibet } \\
\text { type } \\
\text { laster }\end{array}$} & \multicolumn{4}{|c|}{ Grønland } & \multicolumn{5}{|c|}{ Fragtfart } \\
\hline & & & $\begin{array}{l}\text { ud } \\
\text { nr. }\end{array}$ & dato & $\begin{array}{l}\text { ind } \\
\mathrm{nr} .\end{array}$ & dato & $\begin{array}{l}\text { ud } \\
\text { nr. }\end{array}$ & dato & til & $\begin{array}{l}\text { ind } \\
\text { nr. }\end{array}$ & dato \\
\hline $1723 a$ & Jens Jørgensen & g 10 & & & & & & & $\mathrm{E}$ & 42 & \\
\hline $1731 t$ & $\begin{array}{l}\text { Jens Jørgensen } \\
\text { Christen Rasmussen } \\
\text { Anders Bejer, Schads }\end{array}$ & $\begin{array}{ll}\text { g } & 10 \\
\text { g } & 12 \\
\text { h } & 12 \frac{1}{2} \\
\end{array}$ & $\begin{array}{l}5 \\
6 \\
7\end{array}$ & $\begin{array}{l}4.4 . \\
4.4 . \\
4.4 .\end{array}$ & & & $\begin{array}{l}21 \\
22\end{array}$ & $\begin{array}{r}27.7 . \\
5.8 .\end{array}$ & $\begin{array}{l}\mathrm{E} \\
\mathrm{E}\end{array}$ & & \\
\hline $1733 t$ & $\begin{array}{l}\text { Jens Jørgensen' } \\
\text { Christen Rasmussen } \\
\text { Jens Jespersen }\end{array}$ & $\begin{array}{ll}\text { g } & 10 \\
\text { g } & 12 \\
\text { h } & 12 \frac{1}{2} \\
\end{array}$ & $\begin{array}{l}7 \\
8 \\
9\end{array}$ & $\begin{array}{l}22.3 . \\
22.3 . \\
22.3 .\end{array}$ & & & & 23.7. & $\mathbf{E}$ & & \\
\hline $1742 a$ & Jens Jespersen & 14 & & & & & & & & & \\
\hline $1744 a$ & $\begin{array}{l}\text { Christen Rasmussen } \\
\text { Jørgen Jørgensen } \\
\text { (Deign) }\end{array}$ & g 28 & & & & & 15 & & $\begin{array}{l}\mathbf{E} \\
\mathbf{F}\end{array}$ & 13 & \\
\hline $1745 a$ & Jørgen Jørgensen & g 28 & & & & & & & $\mathbf{H}$ & 2 & \\
\hline $1747 \mathrm{a}$ & $\begin{array}{l}\text { Christen Rasmussen } \\
\text { Jørgen Jørgensen }\end{array}$ & $\begin{array}{ll}\text { g } 15 \\
\text { g } 28\end{array}$ & & & 8 & & 16 & & $\mathbf{N}$ & & \\
\hline $1753 a$ & Christen Rasmussen & & 7 & & & & & & & & \\
\hline $1757 \mathrm{a}$ & Jesper Jergensen & 28 & & 30.3 . & 20 & & & & & & \\
\hline $1758 \mathrm{a}$ & Jesper Jørgensen & 28 & 6 & & & & & & & & \\
\hline $1760 \mathrm{a}$ & $\begin{array}{l}\text { Hans Corneliussen } \\
\text { Niels Christensen }\end{array}$ & 28 & & & & & $\begin{array}{l}33 \\
34^{2}\end{array}$ & & E & 2 & 2.1 .61 \\
\hline $1761 t$ & $\begin{array}{l}\text { Hans Corneliussen } \\
\text { Niels Christensen }\end{array}$ & $\begin{array}{l}\text { g } 28 \\
\text { g } 25\end{array}$ & $\begin{array}{l}10 \\
11\end{array}$ & $\begin{array}{l}21.3 . \\
21.3 .\end{array}$ & $\begin{array}{l}11 \\
12\end{array}$ & $\begin{array}{l}22.7 . \\
22.7\end{array}$ & 22 & 18.8. & $\mathrm{E}$ & 18 & 23.11 . \\
\hline $1762 a$ & $\begin{array}{l}\text { Hans Corneliussen } \\
\text { Niels Christensen }\end{array}$ & $\begin{array}{l}\text { g } 28 \\
\text { g } 25\end{array}$ & $\begin{array}{l}4 \\
5\end{array}$ & & 8 & & & & & & \\
\hline $1763 t$ & Hans Corneliussen & g 28 & 7 & 18.3. & 4 & 27.6. & 16 & 12.8 . & E & 11 & 5.11. \\
\hline $1767 \mathrm{t}$ & Niels Christensen & g 28 & 8 & 12.3 . & 17 & 9.8 . & 22 & 17.8 . & E & 25 & 24.11 . \\
\hline $1768 \mathrm{a}$ & Niels Christensen & g 28 & & & $8^{3}$ & 23.6 . & & & & 36 & $28.10 .^{3}$ \\
\hline $1769 t$ & Hans Darum & g 28 & 9 & 25.3. & 18 & 18.7. & 23 & 4.8. & $\mathbf{S}$ & 41 & 24.10 . \\
\hline
\end{tabular}

1. Kunne være den Jens Jørgensen, skipper af "Duen«, der iffg. gravsten på Rømø kirkegård mi maj 1736 blev i Grønland med Skibb og Folck, 43 Aar og 8 Maaneder «.

2. Tran til Ribe.

3. Niels Christensen kom som nr. 8 fra Hamborg til Tønder, hvorfra han under nr. 36 meldte sig tilbage. Han havde ventet pa Rømø for fragt og ville nu forberede forårsrejsen til Grønland. Men det blev ábenbart ikke til noget; rederiet blev omdannet til Grønlandsselskabet og kommandøren udskiftet. 
Alligevel må der være nogen sandhed bag Pontoppidans oplysninger, idet han fik en stor del af sit kendskab til selve hval- og sælfangsten fra Peder Jensen Manøe, ${ }^{21}$ født 1732 på Rømø, der havde stor viden om øens forhold i 1700 -tallet, hvilket hans efterladte papirer viser. ${ }^{22}$ Det er tidspunktet for sælfangstens start omkring 1685 og tallet på 10-11 skibe, der er tvivlsomt, i det mindste for Rømøs vedkommende.

Dog findes der senere bevis for, at et mindre antal Rømø-skibe deltog i sælfangsten ved Grønland.

\section{Salfangst fra Romo - 1705 til 1770}

Den 12. august 1705 dukker der for første gang noget op i mantegnelser « for List toldregnskabet. ${ }^{23}$ Revisoren har bemærket, at sælskind udført fra Rømø til Glückstadt kun blev fortoldet med den halve toldsats. Tolderens kommentar er fornøjelig: "Formoder allerydmydigst at maa passere, som anført er, thi ellers skal vel ingen efterdags saadan raa Sælhundeskind mere angiffe og fortolde, eftersom alle saadanne fangis uden Toldstedets District og tagis saa til Hjemsted, derefter videre til Fremmedesteder lader forføre. " Men toldkammeret deciderer: "Differencen vil betales.« På grund af den forholdsvis ringe mængde af sælskind - en værdi af 16 rigsdaler svarede måske til 5 snes huder - og den åbenbare usikkerhed om fortoldningen kan man vel se episoden som tegn på, at sælfangst var nyt i toldstedets område.

Derefter findes der noget den 3. december 1716. ${ }^{24}$ Da sejler skipper Lauritz Michelsen af Rømø med sin 1 læsters skude til Tønder med 82 tønder tran »af dette Aars fra Grønland hjemførte Sælflæsch «, og der nævnes 3 skibe, der var kommet derfra, og dette spæk var blevet afbrændt på Rømø. Skipperen betaler 13 rd. og 72 sk. told, svarende til ca. $2 \%$ af værdien. Leveringen kan næppe have været udbyttet fra alle 3 skibe, i så fald var det et ganske dårligt fangstår.

For 1717 og 1718 ligger der en vareliste fra List toldsted i regnskaberne, også indeholdende sælskind og tran (se tabel 3a). Sommeren 1718 udfører skipper Hans Hansen Duhn sælskind fra Rømø for 94 rd. ${ }^{25}$

Fra 1723 til 1769, året med den sidst bevarede toldbog fra List toldsted, får vi så mange oplysninger om sælfangstskibe og deres færd, at disse bedst vises $i$ en samlet oversigt, tabel $1 .{ }^{26} \mathrm{Og}$ dermed kan man allerede vurdere omfang og udvikling af Rømøs direkte, ganske vist relativt beskedne deltagelse i grønlandsfarten.

En skibsliste fra 1738 for $»$ List Toldsteds District ${ }^{27}$ giver følgende supplerende informationer: 


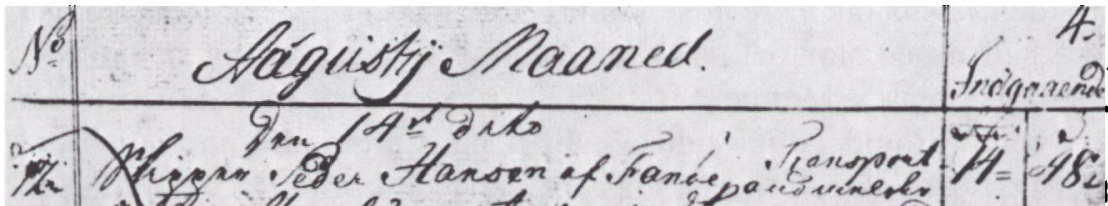

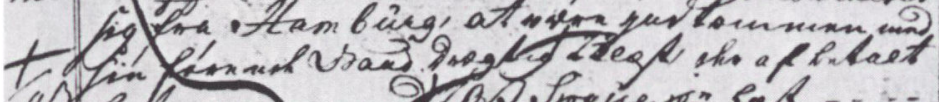

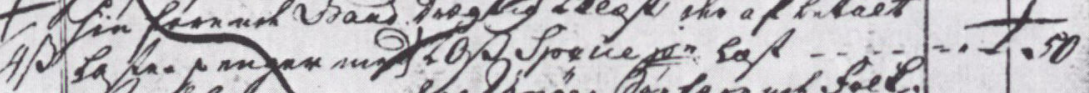

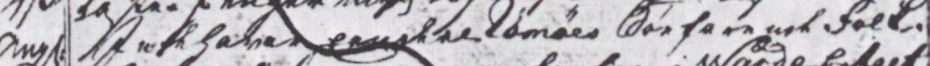

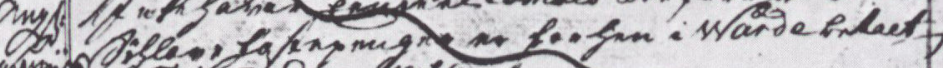
ram

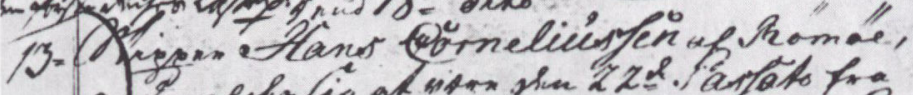

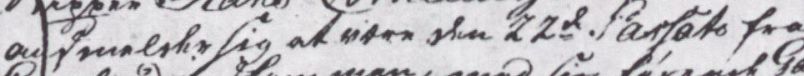

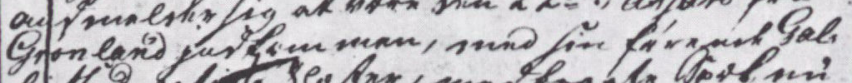

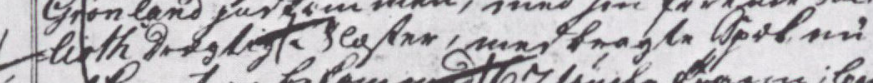

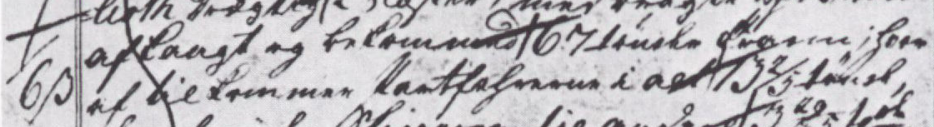

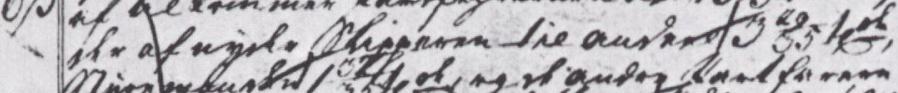

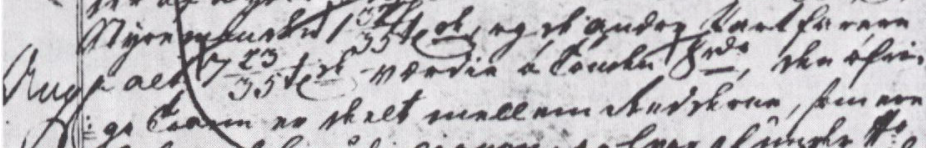

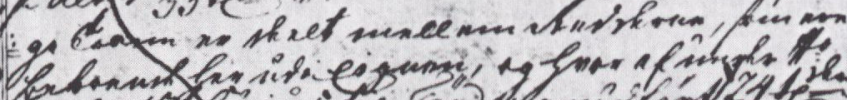

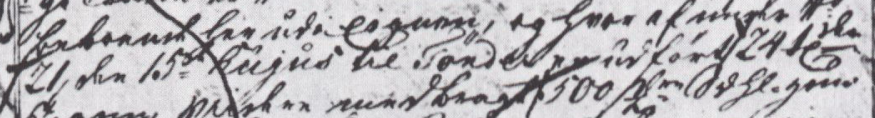

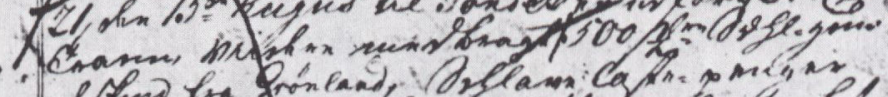

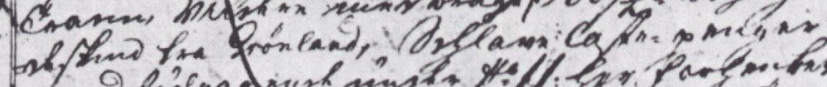

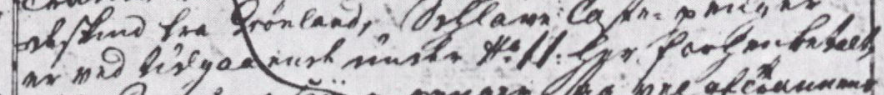

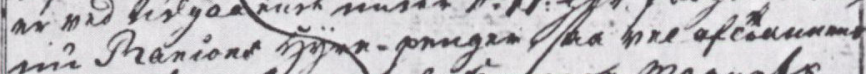

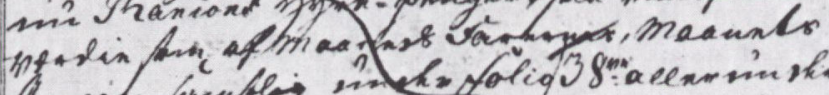

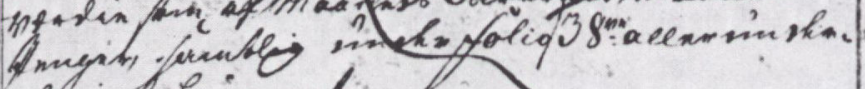
vang hasinent.

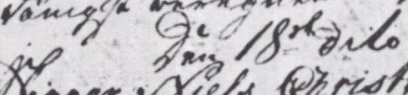

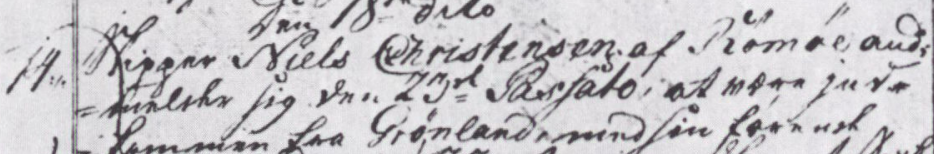

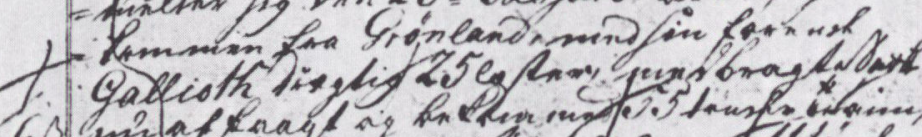

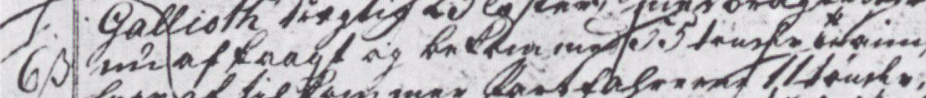

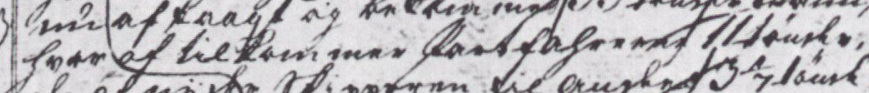

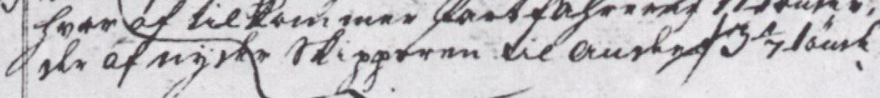
$i^{2}$

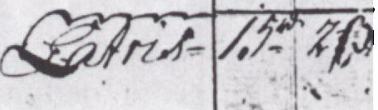

Side af List toldbog august 1761 med Romos to grenlandsskibe. Deres hjemkomstdato og fangstudbytte er angivet (if. tabel 1). 


\begin{tabular}{|c|c|c|c|}
\hline Fahrtøyernis Bygnings Facon & $\begin{array}{l}\text { Dregtigh. } \\
\text { Laster }\end{array}$ & $\begin{array}{l}\text { Alder } \\
\text { Aar }\end{array}$ & $\begin{array}{l}\text { Stædernis Havn } \\
\text { hvor de ere bygt }\end{array}$ \\
\hline 1 Gallioth & 16 & & \\
\hline 1 dito & 15 & 10 & Eklenföer \\
\hline 1 Pinck & 14 & & Engelsk \\
\hline 1 Smack & 11 & 21 & Sydfald \\
\hline 1 dito & $10 \frac{1}{2}$ & 21 & Hollandsk \\
\hline 1 dito & $10 \frac{1}{2}$ & 17 & dito \\
\hline 1 dito & $10 \frac{1}{2}$ & 15 & dito \\
\hline 1 Schytt & 6 & & Eideren \\
\hline 1 Sneck & 2 & 17 & dito \\
\hline $\begin{array}{l}2 \text { dito, som tilhører Østersforpagteren og } \\
\text { bruges allene til at fører Østers til Ham- } \\
\text { borg }\end{array}$ & & & \\
\hline $\begin{array}{l}18 \text { Aabne Baade, som bruges til Østers og } \\
\text { anden Fiskerie }\end{array}$ & $\frac{1}{2} \circ \operatorname{og} \frac{1}{4}$ & & Römmer \\
\hline
\end{tabular}

Ud af selve regnskabet kan man faktisk identificere alle skibe fra 2-11 læster som hjemmehørende på Rømø og brugt til varetransport, mens de 3 største vist nok var til sælfangsten. Den 14-læster »Pinck« kunne

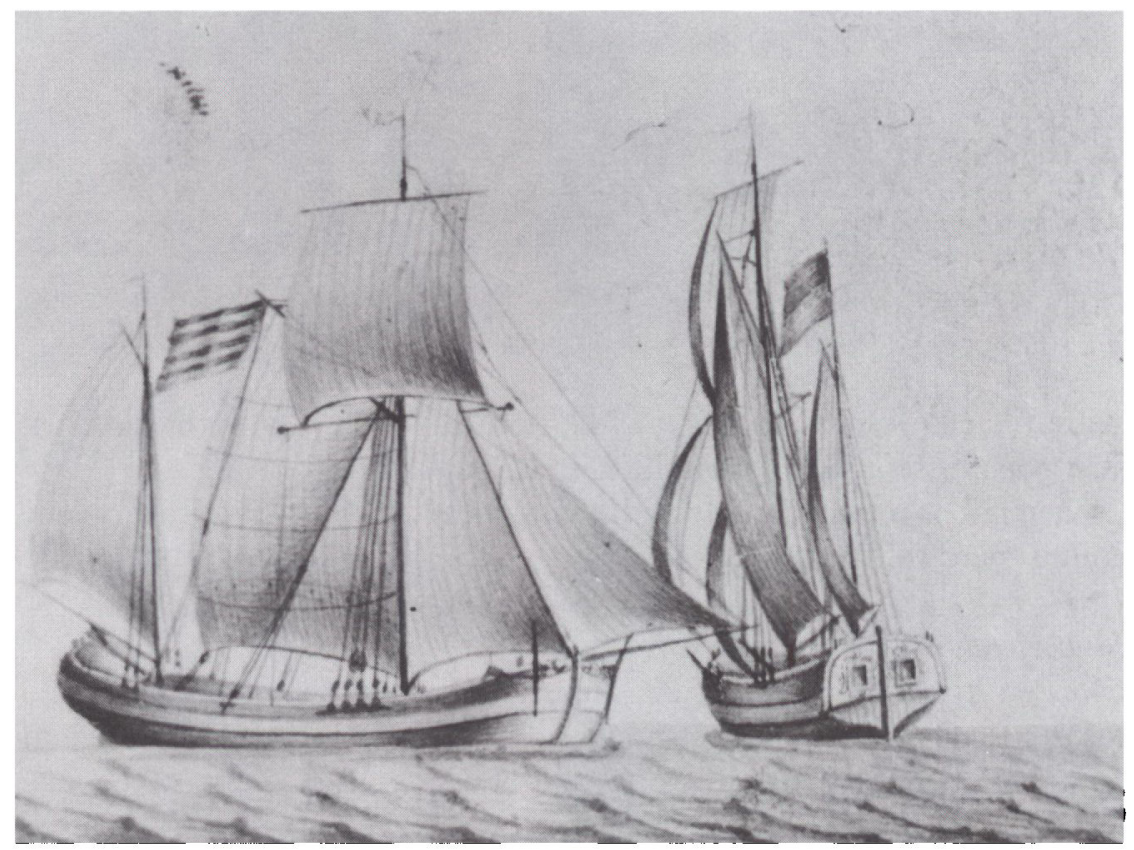

En galiot og en galease, tegnet af Brdr. Stibolt i 1760'erne. (Handels- og søfartsmuseet på Kronborg) 


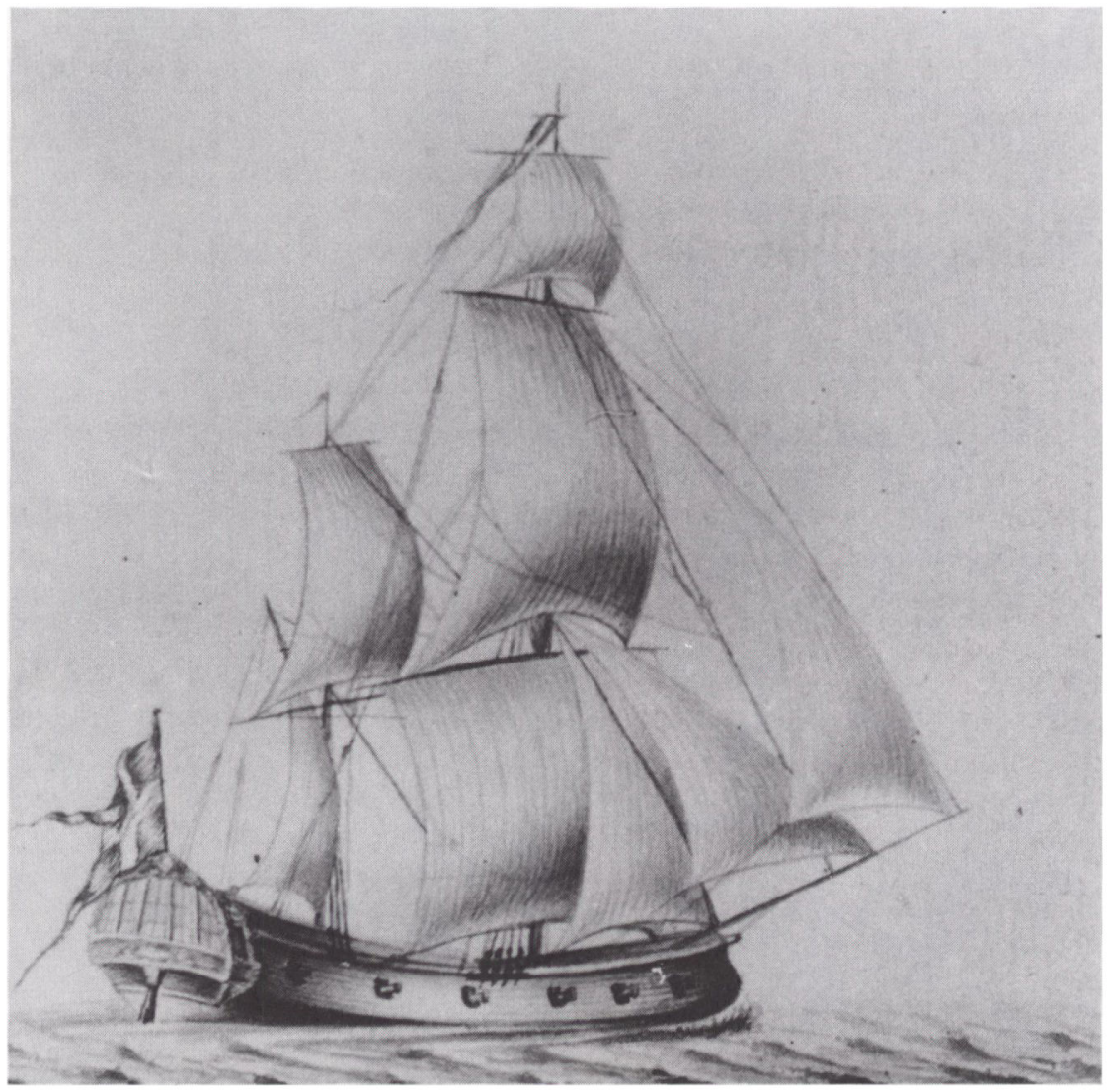

En hukkert, tegnet af Brdr. Stibolt i 1760'erne. (Handels- og sefartsmuseet pd Kronborg)

svare til Jens Jespersens skib i 1742, den 15-læster "Gallioth« til Christen Rasmussens skib i 1744 hhv. 1747 (tabel 1).

Men lad os nu se på nogle andre kilder, der gør billedet af forholdene endnu mere fuldstændigt.

Skibsejendom - en fastlandssag

Efter en kongelig placat af 20. august 1726 skulle skibene måles ved toldstederne. Der er bevaret nogle dokumenter, ${ }^{28}$ såsom målebreve af 14. november 1727 for:

Galiot »Jomfru Anna«, 10 læster stor, hjemmehørende på Rømø, skipper og medejer Jens Jørgensen sammesteds, 
øvrige ejere præst Otto Diderich Lütken og Andreas Bejer i Schads, Poul Thomsen i Ballum, og Lauritz Nissen, Friedrich Petersen og Poul Carstensen i Tønder.

Hukkert »Mercurius«, $12 \frac{1}{2}$ læster stor, hjemmehørende i Schads, skipper og medejer Andreas Bejer sammesteds, øvrige ejere fra Schads og Tønder som ved »Jomfru Anna«.

Det er åbenbart de samme skibe, som findes i 1731 hhv. 1733 i toldbogen. Christen Rasmussens skib eksisterede sandsynligvis endnu ikke i 1727.

Disse ejerforhold i 1727 tyder på en nær forbindelse mellem Tønderkøbmænd og Rømøs grønlandsskibe, hvilket også nævnes af A. M. Møller. ${ }^{29}$ Når man nu hos Wanda Oesau læser om Tønders grønlandsfart, så omtales der for 1739 en kommandør Jens Jespersen på et skib, der om vinteren lå ved Rømø, og der henvises til Tønder byarkiv..$^{30}$ Han må være den samme mand, der i toldregnskaberne 1742 nævnes som hjemmehørende på Rømø. Og ganske rigtigt, i Tønders relationsprotokol findes der den 6. februar 1739 et notat om, at mandskaberne på 3 grønlandsskibe bedes fritaget for »enrolleringen « til flådetjeneste..$^{31}$ Skibene er:

en galiot »Der junge Peter«, tilhørende Baltzer Schmidt og Mathias Tychsen af Tønder, ført af kommandør Anders Beier, Bosholm (tidligere Schads), med 21 mænd og 3 drenge,

en galiot »Christine Lucia«, tilhørende Lorentz (Lauritz) Nissens enke, ført af kommandør Christen Rasmussen, Rømø, med 17 mænd og 2 drenge,

en pink »Fortuna«, også tilhørende Lorentz Nissens enke, ført af kommandør Jens Jespersen, Rømø, med 17 mænd og 2 drenge.

Skibene ligger ved Rømø om vinteren og sejler afsted i slutningen af marts. De er ganske sikkert identiske med de på 1738-listen anførte skibe. Mandskabet hyres på Rømø og på fastlandet.

Ifølge Wanda Oesau skulle Tønder have sendt 7 sælfangstskibe i 1730,5 i 1752 og 3 i 1755. Men der fandtes ingen bevis for det. Et 


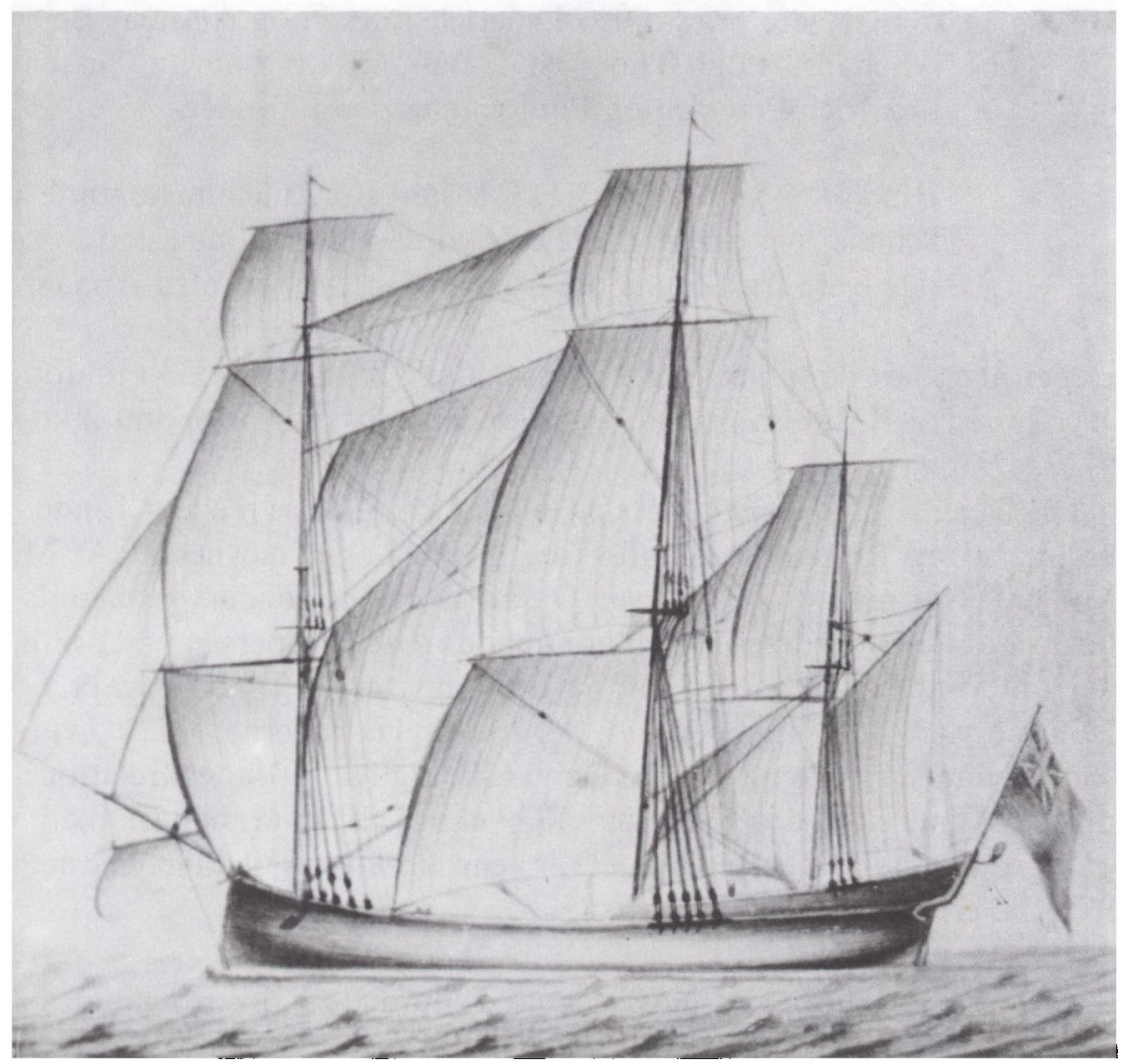

En pink, tegnet af Brdr. Stibolt i 1760'erne. (Handels- og sofartsmuseet på Kronborg)

antal over 3 er dog mindre sandsynligt, efter hvad toldregnskaberne oplyser. Måske udrustede Tønder-købmænd også grønlandsskibe fra andre havne. I toldregnskaberne for 1749 er der f.eks. tale om nogle tønder tran, der indføres fra Altona, men uden told, fordi de var indført direkte dertil fra Grønland på et grønlandsskib ejet af Tønderkøbmænd. ${ }^{32}$

At der stiftedes et Grönländische Compagnie i Tønder 1769, der sendte en 28-læsters galiot ud fra Rømø i 1769 og 1770, bekræftes dog af toldbogen for 1769 .

Tønder byarkiv afslører endvidere noget andet om grønlandsfarten, der passer i billedet. En retssag i 1737 drejer sig om en strid mellem rådmand Peter Henningsen og købmand Thomas Tychsen $\mathrm{i}$ Tønder. ${ }^{33}$ De havde været fælles redere for nogle skibe, deraf et til grønlandsfart 
fra 1716 til 1724. Grønlandsskibet førtes af Hans Alheit, en fra andre arkivalier kendt Rømø-skipper. I det mindste i 1716 og 1719 var skibet også ude for at hente stenkul fra Newcastle om efteråret. På grund af dårlig indtjening ville rederne ikke investere i reparation af skibet efter 1724-togtet. Det blev liggende ved Rømø »ohne Aufsicht«, og til sidst drev det under en storm i vinteren 1726/27 »auf Astrup Acker bei Bröns«. Skibets redere var i alt 8 købmand fra Tønder.

Endnu noget nyt kan man udlede af samme sag. Tønder-købmænd byggede i 1716 et pakhus på Rømø for 1748 rigsdaler. Øen var blevet et lignende lossested for varer til Tønder, som 100 år tidligere for Ribe. Også sælfangsten krævede nogle lagermuligheder, såvel for udrustningen som for togternes udbytte. Da Gottorp og dermed Tønder siden 1713 bl.a. også var blevet inddraget i kongerigets toldvæsen, kunne vareim- og eksport til og fra Tønder udmærket klares gennem Rømø Sønderlands havn, der sådan set var på vej til at blive en rigtig vestkysthavn. Men området kunne til sidst ikke vinde kapløbet med Grådybet. Endnu 100 år senere har de politiske forhold beseglet denne skæbne. Et kort over østersbankerne fra 1724 viser i øvrigt pakhuset og nogle større skibe liggende bag Rømø.

Håndtegnet kort over Ostersbanker ved Romo 1724. Kortet viser pakhuset og tre storre skibe. (Privat eje)

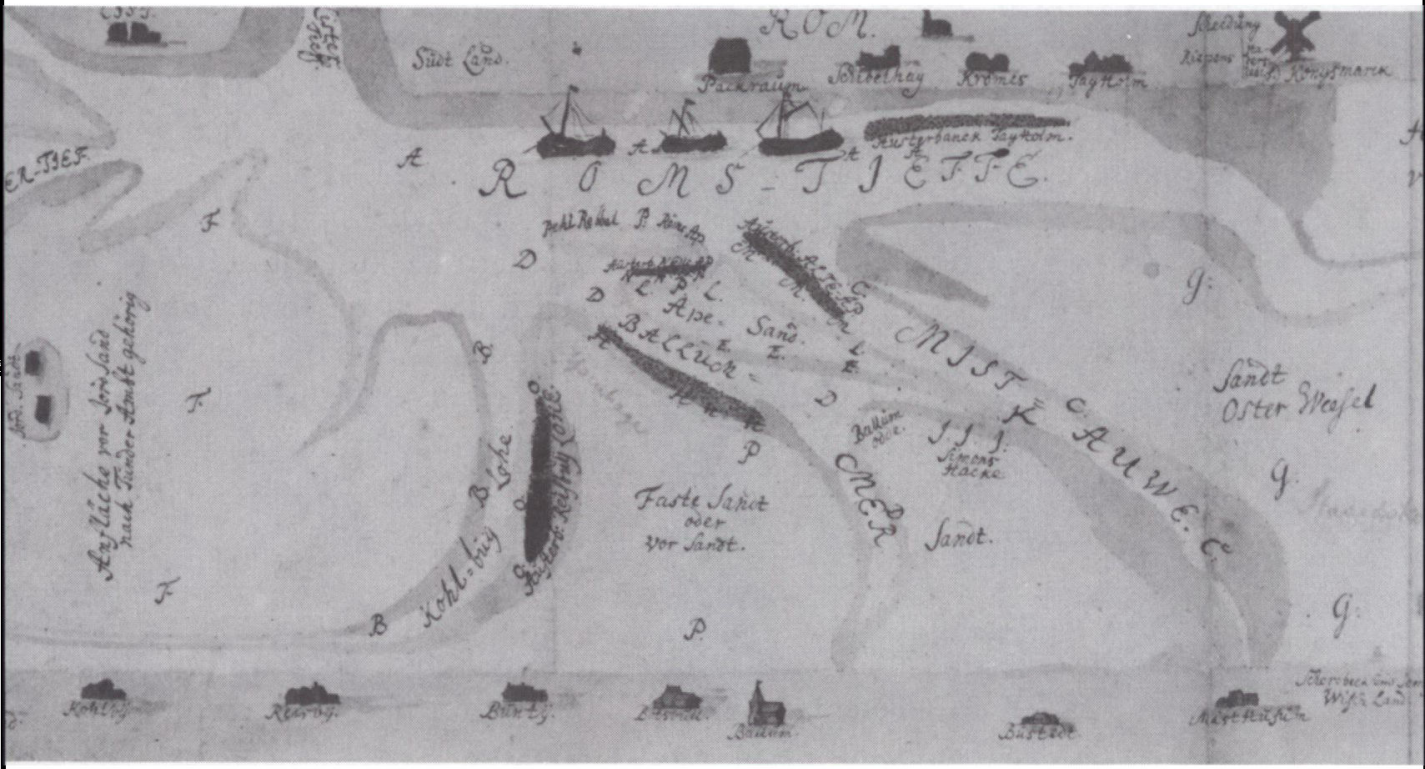


Sammenfatter man nu alle mosaiksten fra de forskellige kilder, så kan man vist sige, at:

Rømø- og Tønder-grønlandsfarten i 1700-tallet faktisk var ens,

dens sælfangst varede i ca. 65 år fra begyndelsen af 1700tallet til 1770 og over en længere periode, mindst fra 1716 til 1739, med 3 skibe, senere aftagende til 2 hhv. 1,

Rømø-beboere, somme tider sammen med nogle fra fastlandet, drev selve farten og også trankogeriet, Tønder-købmænd finansierede foretagendet, tildels $\mathrm{i}$ fællesskab med andre fra fastlandet, og drev tranhandelen.

Det kan overraske lidt, at Rømø-beboerne var så tilbageholdende med at yde penge til øens grønlandsfart. Der var ganske vist kommandører, der kunne have investeret nogle hundrede rigsdaler i 1/8 skibsanpart. Nogle af dem lånte betydeligt større beløb ud, fortrinsvis til gårde på fastlandet. ${ }^{34}$ Der fandtes ligeledes købmænd med tilstrækkelig formue, som f.eks. "Seigneur « Peder Holm af Tagholm, landfoged og kirkeværge på Sønderland Rømø, der sammen med en Ribe-købmand og førnæunte skipper Hans Pettersen Alheit ejede en 16 år gammel 8-læsters smakke "de Kupper« i $1727 .{ }^{28}$ Han efterlod sig bl.a. nogle tusinde rigsdaler, da han døde i $1746 .{ }^{35}$ Man havde jo nok kendskab til grønlandsfarten på Rømø; men svaret ligger måske netop i deres viden om økonomien, der behandles i sidste kapitel.

Sammenligner man sælfangsten fra Rømø med den andre steder i Jylland og i hertugdømmerne i 1700-tallet, så er der kun Elb-udmundingen med Hamborg, Altona og Glückstadt, der havde en betydelig større fangstflåde. Flensborgs sælfangst var i nogle perioder af lignende omfang. Mange andre steder prøvede man at være med, men mest uden held. Ribe skal have haft 1-2 skibe til sælfangst i ca. 40 år, financieret af rådmand Rahr. ${ }^{36}$ Disse overvintrede ved Fanø. A. M. Møller nævner 2 skibe fra Varde tolddistrikt. ${ }^{37}$

Skibe og mandskab

Som skibstype til sælfangsten foretrak man galioten, også fra andre havne. Fra Rømø sejlede man med en lille, vist for det meste en- eller 
halvandenmastet version. En hukkert, senere en pink, blev også brugt i første halvdel af 1700-tallet. Disse typer var nemme at manøvrere, men alligevel stabile, relativt dybtgående skibe, der var velegnede til langfart og vanskelige vejrforhold. Smakker og everter, der ellers var de mest udbredte skibstyper ved vesterhavsøerne, kunne kun bruges i kystområdet.

Størrelsen var, som sagt, forholdsvis ringe, med 10-16 læster indtil 1740'erne, og op til 28 læster til sidst. De første målte ikke mere end op til $15 \mathrm{~m}$ i længden. De lidt større var omtrent $18 \mathrm{~m}$ i længden og 4,5 $\mathrm{m}$ i bredden. Man førte næppe mere end 2, evt. 3 slupper med sig. Men ved vurdering af størrelsen, angivet ved toldstedet, skal man nok tage hensyn til »den lange afstand til København«, der reducerede målingernes resultat. ${ }^{39}$ Fra Flensborg sejlede man med skibe fra 24 læster (Jungfrau Helena, 1748, kommandør Peder Andersen, Rømø) til 46 læster (St. Marien Kirch, 1753, samme kommandør). ${ }^{40}$ Falk gætter på sidstnævnte størrelse også for Hamborgs sælfangstskibe i første halvdel af 1700-tallet, medens størrelser i 1766 angives med 50-130 læster. ${ }^{41}$

Mandskabets og skibets størrelse svarede til hinanden. Mens man på sælfangstskibe med 35-50 læster havde 25-35 mænd, var der her tale om 19-24 mænd på 14-16-læsters skibe. Ud af bidrag til slavekassen (hjælpekasse til søfolk, der måtte købes fri af slaveriet hos sørøvere) kan man se, at Rømøs senere 28-læsters skib heller ikke havde større besætning end 25 mænd. ${ }^{42}$

"Rancon-penges « (sådan kaldtes slavekasse-bidraget) beregning giver i øvrigt også oplysninger om mandskabets hyre. I 1760'erne fik en matros gennemsnitligt ca. 27 sletdaler eller 54 mark for et grønlandstogt. Kommandøren fik 54 mark, styrmanden 36 mark som »Haandpenge«. Men til gengald deltog de jo, ligesom en del af det øvrige mandskab, som "partfarer« $\mathrm{i}$ togtets udbytte.

Hele parten var på $20 \%$ af trannen, hvoraf kommandøren fik knap $30 \%$, styrmanden knap $15 \%$, og de andre "partfarer $\mathrm{i}$ alt knap $60 \%$. Hans Corneliussen, der i øvrigt var kommandør i 1757 på sælfangstskibet Frau Helena af Flensborg, 40 læster, 30 mænd, fik således i 1761 $3^{29} / 35$ tønder tran. ${ }^{43}$ Toldværdien var $8 \mathrm{rd} .=24$ mark pr. tønde; men den kunne givetvis sælges noget dyrere. Hvorvidt han også havde anparter i skibet, hvilket åbenbart var sædvane i 1727 og dermed deltog i togtets økonomiske resultat, vides ikke. 


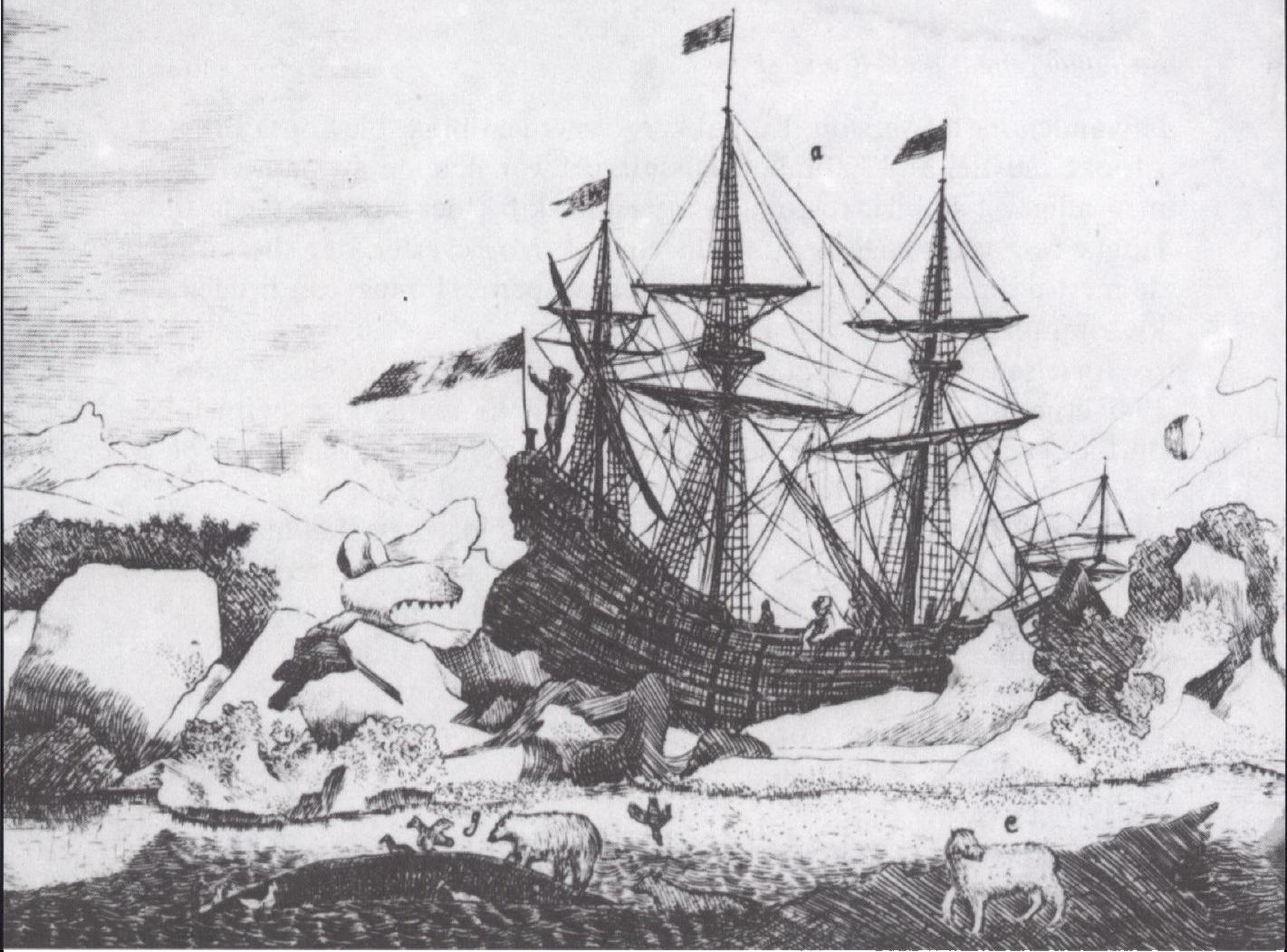

Gronlandsskibe, knust $i$ isen. (Efter Fr.Martens: Spitzbergische oder grönländische Reisebeschreibung; 1676)

\section{Arets lob}

Selve grønlandstogtet varede jo ikke ret længe. Man sejlede samlet afsted og blev sandsynligvis i en konvoj under hele turen. Afrejsedatoer mod slutningen af marts ligger forholdsvis sent for sælfangsten, efter hvad andre kilder oplyser. ${ }^{44}$ Måske var de små Rømø-skibe ikke så velegnede til at sejle $\mathrm{i}$ isfyldte farvande. Kun $\mathrm{i} 1767$ sejlede man allerede den 12. marts; men det var åbenbart et meget varmt forår, da også Øresundstrafikken var usædvanlig livlig allerede i marts måned. $.^{45} \mathrm{R} \varnothing-$ mø-skibene kom normalt tilbage efter 3-4 måneder, 1767 igen undtaget, hvor den ene 28-læsters galiots rejse varede 5 måneder; men fangsten var med 35 cordeler spæk alligevel ikke tilfredsstillende. Kun 8 dage efter hjemkomsten tog man så, ledig, til England for at søge fragt og dermed yderligere fortjeneste.

Følgende var i øvrigt normalt for Rømøs grønlandsskibe, hvilket Pontoppidan senere, i 1785, generelt anbefaler til hval- og sælfangstski- 
Tabel 2. Mandskabets hyre pr. dr i mark

( 1 rigsdaler $=3$ mark, 1 sletdaler $=2$ mark)

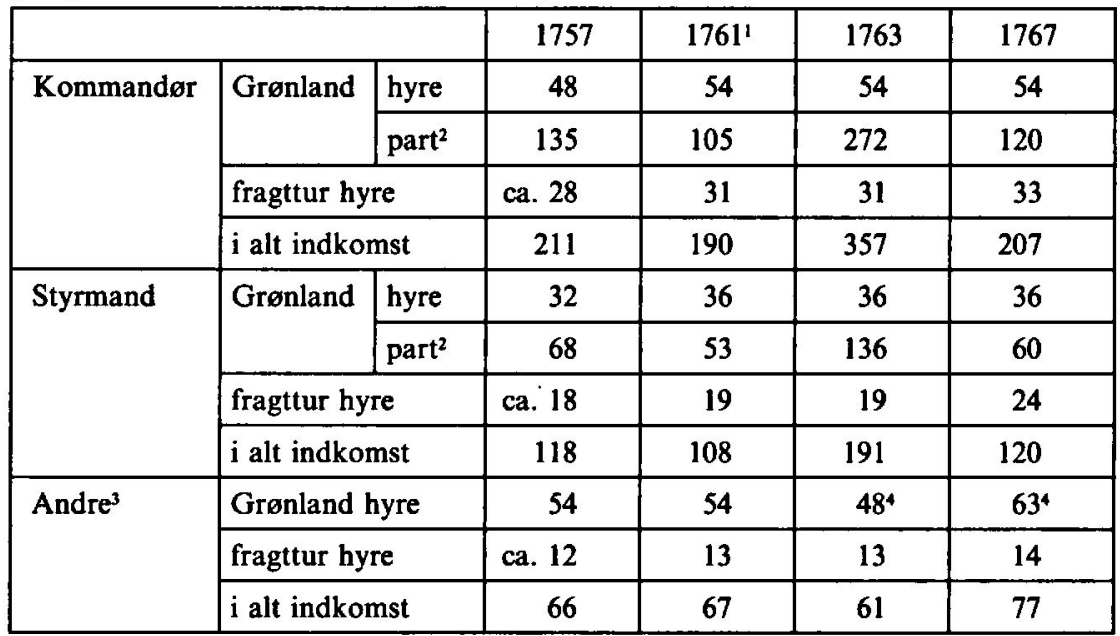

1. Gennemsnit af begge skibe.

2. $1 \mathrm{td}$. tran ansat til $10 \mathrm{rd}$. $=30$ mark.

3. Gennemsnit, uden evt. parter.

4. 1763 tidlig, 1767 sen hjemkomst.

for 70 tønder. For 1769 findes der ingen angivelse af fangsten; men skibet sejlede allerede igen efter 17 dage, den 4. august, på fragttur til Østersøen, og det passerede Øresund den 16. august. ${ }^{47}$

Der findes $\mathrm{i}$ øvrigt to andre interessante oplysninger $\mathrm{i}$ toldbogen 1769. Søren Ambders af Rømø, dengang mindst 65 år gammel, en søn af præst Andreas Ambders (1693-1733), sender den 23. september „48 potter tran og 36 stk. skind af de af ham fangede sælhunde« til Tønder. Åbenbart drejede det sig om en småfangst fra området. Den anden sag drejer sig om, at ikke mindre end 20 Fanø-både på mellem $\frac{1}{2}$ og $3 \frac{1}{2}$ læsters størrelse kom ind med Rømø-søfolk fra Elben i tiden mellem den 4. juli og den 4. november 1769. Når Falk angiver 206 mænd fra Rømø som grønlandsfarere fra Hamborg i 1768, og man dertil må antage yderligere 50 fra Altona, så har Fanø-flåden overtaget størsteparten af transporten. ${ }^{48}$

\section{Salfangstens økonomi}

Hvad var så sælfangstens resultat? Tabel 3 giver en oversigt over, hvad vi ved om fangstens udbytte, og det er desværre ikke så meget. Mens 
Beffhreibung der TKANBRENNVEXX

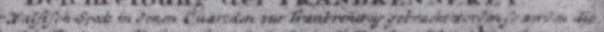

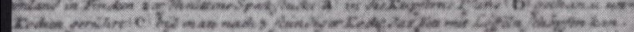

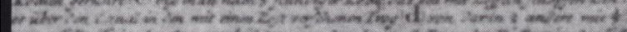

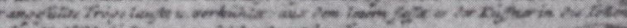

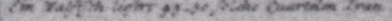

Trankogeriet pd Romo. (Kobberstik fra 1752 pd Romø Vandrehjem)

Tabel 3. Romo-salhundefangstens resultat

a) Udforsel af varer fra Rome

\begin{tabular}{|c|c|c|c|}
\hline Ar & $\begin{array}{l}\text { antal } \\
\text { skibe }\end{array}$ & tdr. tran & stk. skind \\
\hline 1705 & 3 & 82 & ca. 100 \\
1716 & 3 & $138 \frac{1}{2}$ & 340 \\
1717 & & 103 & 1570 \\
1718 & & \\
\hline
\end{tabular}

b) De enkelte skibes udbytte

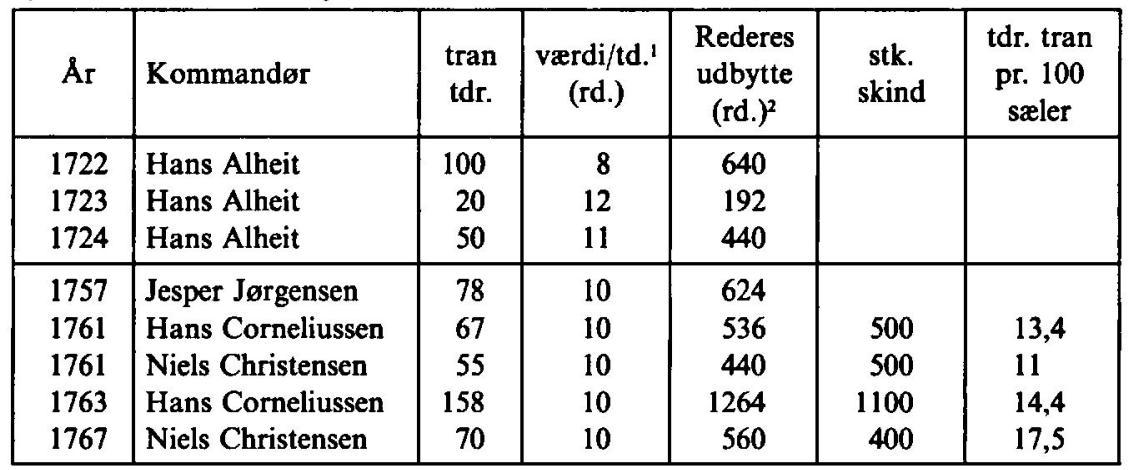

1. 1722-24 ud af rederens interne afregning, 1757-67, se tekst.

2. $80 \%$ af $\operatorname{tran} \times$ værdi. 


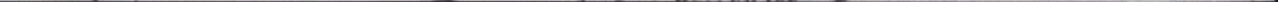


tabel 3a) sandsynligvis kun. viser en del af årenes totale fangst, er tallene $\mathrm{i}$ tabel $3 \mathrm{~b}$ ) brugbare til at vurdere de enkelte skibes resultat.

For Hans Alheits skib 1722-1724 kan man opstille følgende regnestykke over et års omkostninger:

skibets købspris med to slupper, ca. 1600 rd., kræver årlig afskrivning med $8 \%$ og $4 \% \mathrm{i}$ rente, $\mathrm{i}$ alt pr. år $192 \mathrm{rd}^{49}$ den årlige udrustning med hyre kostede $650-700 \mathrm{rd} .^{50}$

Intet under, at rederne ikke ville fortsætte efter 1724 !

De større skibe fra den senere periode var nok noget dyrere, måske ca. 2500 rd. Afskrivning og rente kommer så i alt på 300 rd., og udrustningen har vel årligt kostet ca. 800-850 rd.

Når man ser bort fra året 1763 var det ikke en god forretning. Ikke engang sammen med sælskindssalget kunne den gennemsnitlige indtægt af de anførte 5 togter dække de løbende, direkte omkostninger. I øvrigt var sælerne relativt små, med omkring 15 tønder tran pr. 100 sælhunde. Ifølge Norman svarer det til udbyttet af unge sæler. ${ }^{51}$

Tranpriserne $\mathrm{i}$ den senere periode er måske sat for lavt. I toldregnskaberne regnede man kun med $8 \mathrm{rd}$./td. Men dette blev kritiseret af revisionen, der bemærkede, at prisen i København var på mere

Tabel 4. Kommandorernes hjemstavn (efter fasteprotokollerne)

\begin{tabular}{|c|c|c|c|c|}
\hline Navn & Hjemstavn & $\begin{array}{l}\text { Be- } \\
\text { vist }\end{array}$ & $\begin{array}{l}\text { Sand- } \\
\text { synligt }\end{array}$ & $\begin{array}{l}\text { I faeste } \\
\text { siden år }\end{array}$ \\
\hline Hans Alheit & gård, Sønderby & $x$ & & 1) \\
\hline $\begin{array}{l}\text { Jens Jørgensen } \\
\text { ("Duen«) }\end{array}$ & gård, Duhnby & $x$ & & 1724 \\
\hline Christen Rasmussen & kåd, ? & $x$ & & 1730 \\
\hline Jens Jespersen & gård, Westergaarde & & $x$ & 1730 \\
\hline $\begin{array}{l}\text { Jørgen Jørgensen } \\
\text { (Deign) }\end{array}$ & gård, Wraa & & $x$ & 1735 \\
\hline Jesper Jørgensen & gård, Wraa & $x$ & & 1766 \\
\hline $\begin{array}{l}\text { (Deigns søn) } \\
\text { Hans Corneliussen }\end{array}$ & $? \quad ?$ & & & \\
\hline Niels Christensen & gård, Westergaarde & & $x$ & 1766 \\
\hline Hans Darum & gård, Østerby & $\times$ & & 1766 \\
\hline Søren Ambders & gård, Kirkeby & $x$ & & 1729 \\
\hline
\end{tabular}

1. Alheits slægtsgård. Hans Alheit havde senere (fra 1721) en helkåd $\mathrm{i}$ fæste.

4 Kort over Romo 1796, tegnet af S.Bruun. (Geodatisk Institut) 
end det dobbelte. Man krævede en toldværdi af mindst $10 \mathrm{rd} . / \mathrm{td} . .^{52}$ Pontoppidan nævner op til $17 \mathrm{rd} . / \mathrm{td}$. for 1785 efter kvalitet. ${ }^{53}$ Så har Tønder-købmænd måske opnået en bedre pris. Men til dækning af både omkostninger, afskrivninger og renter skulle indtjeningen af de 5 togter $\mathrm{i}$ gennemsnit have været omtrent $75 \%$ bedre. Og så mangler der endda omkostninger til tranbrænderiet, lagerføring og transport $\mathrm{i}$ regnskabet.

Alt $\mathrm{i}$ alt er der vel ingen tvivl om, at foretagendet ikke har lønnet sig for skibenes redere. Man forstår nu også bedre, hvorfor Rømøbeboere med Grønlandserfaring holdt deres penge ude af forretningen. Men 30-60 familier på Rømø kunne dog ernære sig af Rømøs grønlandsfart i denne periode, der i øvrigt bød på en udmærket uddannelse for øens andetsteds så efterspurgte sælfangstspecialister.

\section{LITTERATUR OG KILDER}

I. Staatsbürgerliches Magazin, bd. IV, Schleswig 1824, S. 651, Nachrichten von der Insel Römoe«.

II. C. Pontoppidan: Hval- og Robbesfangst, København 1785.

III. C. Norman: Hval-, Hvalros- og Sælhundefangstens Historie og Udvikling, Tidsskrift for Søvæsen, Ny række, 1. bd. og 2. bd., København 1865 hhv. 1867.

IV. W. Oesau: Schleswig-Holsteins Grönlandsfahrt, Glückstadt 1937.

V. Th. Petersen: Rømø, Åbenrå 1979.

VI. H. E. Sørensen: Rømøs historie, Skærbæk 1977.

VII. F. J. Falk: Grönlandsfahrer der Nordseeinsel Römö, Bredstedt 1983.

VIII. Rigsarkivet, Rentekammerets reviderede regnskaber, List og Amrum toldregnskaber 1680-1771, 5 pk.

IX. Rigsarkivet, Øresund toldregnskaber 1497-1783.

X. Rigsarkivet, Søetaten.

XI. Landsarkivet, Åbenrå, Ballum birks tingbøger, nr. 2396 1702-1718, nr. 23971718 1737, nr. 2395 1689-1702.

XII. Rigsarkivet, Rentekammer, nr. 2215.332, skibsmåling.

XIII. A. M. Møller: Fra Galeoth til Galease, Esbjerg 1981.

XIV. Landsarkivet, Åbenrå, Tønder byarkiv.

XV. J. H. P. Barfod, Danmark-Norges handelsflåde, Kronborg 1967.

XVI. Handels- og Søfartsmuseet, Kronborg, kartotek.

Romertallene angiver forkortelser $i$ noter og henvisninger.

\section{NOTER OG HENVISNINGER}

1. I, s. 662 .

2. II, s. 87.

3. II, s. 17.

4. III, 2. bd., s. 41 og 530 .

5. IV, s. 190. 
6. V, s. 68 .

7. VI, s. 70.

8. VII, s. 25.

9. VIII, pk. 1-5.

10. IX, 1767, bd. 1635, 30.4., 18.7. og 1.10.; bd. 1637, 26.8 .

11. X, indk. sager til krigskancelliet, 1695, pk. 504, sag nr. 308 .

12. X, indk. sager til krigskancelliet, 1694, pk. 503, sag nr. 24.

13. X, Kommissariatskontoret, fortegnelse over skibe i Danmark 1677-79.

14. XI, nr. 2396, 15.3. og 16.4.1704 samt nr. 2395, 25.8.1699.

15. VIII, pk. 1, ant. 1683 , beviser.

16. IX, 1686, bd. 1, 11.4. og 25.6.; bd. 2, 16.5.

17. $X$, indk. sager til krigskancelliet, 1690, pk. 499b, journal 21.10.1689.

18. VIII, pk. 1, skibsliste 1690 .

19. VIII, pk. 1, varelister 1681-85.

20. VIII, pk. 1, ant. 1682 .

21. II, s. 44.

22. V, noter $39,60,123,124,133,134,146,150,157$.

23. VIII, pk. 1 , ant. 1705 .

24. VIII, pk. 2, ant. 1716.

25. VIII, pk. 2, varelister 1717-18.

26. VIII, pk. 2-5.

27. VIII, pk. 3, 1738.

28. XII.

29. XIII, s. 112 .

30. IV, s. 193.

31. XIV, pk. 88.

32. VIII, pk. 3, ant. 1749.

33. XIV, pk. 364.

34. V, s. 113.

35. Testamente i privateje.

36. II, s. 17.

37. XIII, s. 113.

38. XV, s. $111 \mathrm{ff}$.

39. XIII, s. 46.

40. XVI.

41. VII, s. $28,42-47,62$.

42. VIII, pk. 4 og 5, toldbøger 1761, 1763 og 1767.

43. VII, s. 42.

44. VII, s. 46 , også III beskriver selve fangsten i april.

45. IX, 1767.

46. VIII, div. ant. over hele perioden.

47. IX, bd. 1, 16.8.; bd. 2, 9.9.

48. VII, s. 56.

49. XI, nr. 2397, 5.8.1718.

50. XIV, pk. 364 .

51. III, bd. 2, s. 553.

52. VIII, pk. 4, ant., 1761.

53. II, s. $22 \mathrm{ff}$. 
